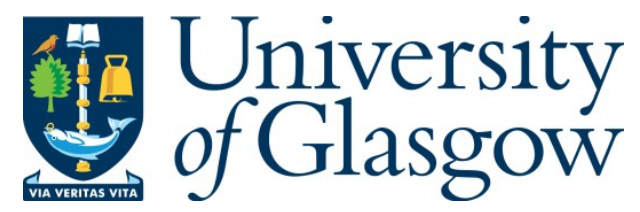

Van Puyvelde, D. (2020) Profiles in intelligence: an interview with Sir David Omand. Intelligence and National Security, 35(2), pp. 171-178.

(doi: $\underline{10.1080 / 02684527.2019 .1706875)}$

This is the Author Accepted Manuscript.

There may be differences between this version and the published version. You are advised to consult the publisher's version if you wish to cite from it.

https://eprints.gla.ac.uk/206245/

Deposited on: 7 January 2020

Enlighten - Research publications by members of the University of Glasgow http://eprints.gla.ac.uk 


\section{Profiles in Intelligence: an interview with David Omand}

\section{Introduction}

Sir David Omand GCB is currently a visiting Professor in the War Studies Department at King's College London. During his career in British government service he held senior posts in defence, intelligence and security including serving for seven years on the UK Joint Intelligence Committee in the 1990s and 2000s.

Sir David teaches intelligence studies at King's College, at PSIA Sciences Po in Paris and at the Norwegian Defence University in Oslo, and is a member of the external advisory boards for the Centre for Asymmetric Threat Studies in Stockholm and for the German Federal University Masters course in Intelligence and Security Studies. He continues to provide advice to government and helps train government intelligence analysts.

Sir David was a Foundation Scholar in economics at Corpus Christi College, Cambridge. After graduating he began his career at the Government Communications Headquarters (GCHQ), Britain's code-breaking and signals intelligence agency. He has held a number of influential positions within the Ministry of Defence including Principal Private Secretary to the Secretary of State during the Falklands conflict, and Deputy Under Secretary of State for Policy during the Bosnian war. He also served as UK Defence Counsellor to the North Atlantic Treaty Organisation in Brussels, Belgium. He was the Director of GCHQ in 1996-97 before being appointed Permanent Secretary of the Home Office. His final post in public service was as Permanent Secretary in the Cabinet Office serving as the first UK Security and Intelligence Coordinator (2002-2005). After the events of 9/11, he formulated Britain's counter-terrorism strategy, CONTEST, still in force today (2019).

He has published a range of scholarly articles and two books, Securing the State (London: Hurst/Columbia 2010) and (with Mark Phythian, the editor of this journal) Principled Spying: the Ethics of Secret Intelligence (Oxford/Georgetown University Press, 2018). His next book How Spies Think: 10 Lessons from Secret Intelligence will be published by Penguin Viking in June 2020. He co-authored the first study of what he termed SOCMINT, 'social media intelligence', which analysed the potential use of social media for intelligence purposes. ${ }^{1} \mathrm{His}$ paper entitled Digital Intelligence and the Norms that should Govern It (London, 2015) played an important role in shaping the outcome of Carl Bildt's Global Commission on Internet Governance (2015). He was a member of the RUSI Independent Surveillance Review, A Democratic Licence to Operate, commissioned by the UK Deputy Prime Minister and that contributed to the passing of the Investigatory Powers Act of November 2016. And the review he chaired on The Security Implications of Drones (Birmingham, 2014) made a significant contribution to the evolution of British policy on the use of Unmanned Aerial Vehicles. His contribution to the academic study of intelligence and security issues has been widely recognised and he has received Honorary Doctorates from the University of Birmingham and the University of Glasgow.

\footnotetext{
${ }^{1}$ David Omand, Jamie Bartlett and Carl Miller, 'Introducing Social Media Intelligence (SOCMINT)', Intelligence and National Security 27/6 (2012): 801-823.
} 
After retirement from the Civil Service, Sir David studied mathematics and theoretical physics with the Open University and was awarded a First Class honours degree. He continues to contribute to the study and practice of security policy as a Distinguished Fellow of the Royal United Services Institute and as a member of the editorial board of this journal. He is a frequent contributor to national debates on security issues on television, radio and in the media. He is the senior independent director of Babcock International Group plc that provides critical, complex engineering services for UK defence and international customers and is a senior advisor to Paladin Capital Group, a global investor that supports innovative cyber technology companies.

The transcript below is based on an interview first conducted with Sir David at my office at the University of Glasgow on 25 October 2019. After, I lost the recording due to a manipulation error (lesson learnt: always use two voice recorders), Sir David kindly accepted to pursue the exchange by email. I sent him a revised series of questions to which he replied on 25 November 2019. We revised the transcript and agreed on a final version on 5 December 2019.

\section{Interview}

DVP: Sir David, could you tell me a bit more about your background? With a degree in Economics, what attracted you to intelligence in the first place?

DO: I graduated in 1969 from Cambridge with a double First in Economics and a funded place to pursue a $\mathrm{PhD}$ (on mathematical modelling under conditions of uncertainty). But I woke up one morning and having reread the abstruse research question I had set myself decided I would be better off getting a job. I had already had a short work experience in HM Treasury and knew I did not want to work as an economic adviser. Eventually the Appointments Board at the University pointed me in the direction of GCHQ. I sat their daunting entrance exam - the second GCHQ puzzle book contains some of the exam questions set from that period so you can see just how hard it was. ${ }^{2}$ At my final interview I was grilled by C H O'D Alexander [Colonel Hugh O'Donel Alexander], the international chess master who had worked in Hut 8 at Bletchley Park with Alan Turing and had then become GCHQ's chief cryptanalyst. We had a fierce disagreement about the relative utility of mathematical modelling and econometrics (I felt he won the argument, I recall). I think it was the prospect of tough intellectual challenges in the service of a clear national security purpose that proved irresistible.

DVP: Did you have any preconceived idea of what GCHQ, and its sister agencies, were all about then? If so, what sources (books, reporting, fiction etc.) had influenced your ideas?

DO: In 1969 the existence of the British secret agencies had not been publicly acknowledged and I knew next to nothing about the work of the wider British intelligence community before I joined GCHQ. The only major open work on signals intelligence was David Kahn's The Codebreakers: The Story of Secret Writing that had been published two years before I joined GCHQ, but which revealed almost nothing about the British contribution, such was the then impact of the Official Secrets Act. ${ }^{3}$ Today's recruits have the advantage of a huge intelligence studies literature to inform them (although regrettably in some case misinform them) about what the job of an intelligence officer really is.

\footnotetext{
${ }^{2}$ Government Communications Headquarters, The GCHQ Puzzle Book II (London: Michael Joseph, 2018).

${ }^{3}$ David Kahn, The Codebreakers: The Story of Secret Writing (New York: Macmillan, 1967).
} 
DVP: You served in various senior government positions from the 1980s onward, how effectively do you think the British intelligence and security machinery was prepared for the changes and crises that have characterised the post-Cold war era both in the 1990s and the 2000s)?

DO: The Joint Intelligence Committee did not expect the Berlin Wall to collapse and the Cold War to end when it did so the honest answer must be that British intelligence was as completely unprepared as everyone else. That said, the UK had a number of advantages in adjusting to the new world. One, on the demand side, was that the long campaign in Northern Ireland had created more of a sense of intelligence community and of partnership with the police than in most countries. That proved invaluable in the reorientation towards new customer demands, accelerated greatly by the threat of violent jihadist terrorism with the impact of $9 / 11$ on requirements for actionable intelligence on international terrorist networks. Another advantage, on the supply side, was that GCHQ had a very high level of technical engineering and mathematical expertise and so was able to innovate effectively and adapt to the digital age of the Internet and of the web that really took off around the same time in the 1990s. Overall, the post-Cold War adjustment was nevertheless very painful for those staff, and their families, who found their expertise and language skills no longer relevant and who were caught in the post-Cold War downsizing and reorientation.

DVP: Was there any concern at the time about the effects of such a downsizing, specifically the loss of skills and knowledge this could cause?

DO: Yes, but with the end of the Cold War and the budget constraints of the time there was no alternative but to slim down, losing both civilian and uniformed expertise. That meant in particular closing SIGINT stations that had focussed on the Warsaw Pact armed forces, and on the Group of Soviet Forces in Germany. Some of those stations had been the most innovative in developing new techniques for acquiring and developing intelligence sources and had a considerable depth of institutional expertise.

DVP: In 2002, you became the first UK Security and Intelligence Coordinator. Could you explain the rationale for establishing this position, and what effects it has had on intelligence-policy interactions?

DO: After 9/11, the Cabinet Secretary Sir Richard Wilson (the UK's most senior civil servant) had had to devote a great deal of his time to ensuring clear gaps in UK homeland security were filled and that the intelligence agencies were adapting fast enough to the emergence of this terrorist threat. But when Wilson retired in September 2002 Prime Minister Blair wanted his successor as Cabinet Secretary to focus on the delivery of the government's domestic agenda. I was therefore appointed as a senior Permanent Secretary to take over the Cabinet Secretary's responsibilities for the intelligence agencies (and to be the Accounting Officer for their budget) as well as the traditional duties of Intelligence Coordinator to ensure the health of the intelligence community. The post also had policy responsibilities for coordinating 'homeland security' which quickly came to include constructing and driving forward the UK Counter-Terrorism Strategy CONTEST, still in force today. I re-joined the JIC but the proper separation of policy and intelligence analysis was maintained through having a separate chair of the JIC through whom assessments reached Ministers, and not through me. Bringing counter-terrorism strategy and intelligence community development 
together in my post made sense at that critical time, for example in the creation of the UK Joint Terrorism Analysis Centre in June 2003. But the separation of 'security, intelligence and homeland security' on the one hand and 'foreign and defence policy' on the other (overseen by a senior diplomat acting as the PM's foreign policy adviser) was a weakness, now rectified by having a National Security Council chaired by the Prime Minister and supported by a single National Security Adviser.

DVP: Was there an intelligence and security literature, or any academic literature, which you drew on during your time in the civil service?

DO: I am very struck by the contrast between the relevance of the strategic studies defence literature in comparison with that of intelligence studies. No-one working seriously on nuclear deterrence policy as I did when in MOD in the early 1990s would dream of not studying carefully the literature of thinkers such as Brodie, Buchan, Kahn, Schelling, Kissinger and more recently Quinlan, and keeping up to date with the articles coming out in the journals of the IISS [International Institute for Strategic Studies] and Chatham House. NATO too has its own specialist literature. There was no parallel in the intelligence world at all. Even today, I regret to say, I find few of the 90-odd young British government analysts I help to train each year on courses at King's College have been in the habit of reading INS [Intelligence and National Security] or the International Journal of Intelligence and CounterIntelligence. One of the purposes of these courses is to change that. Of course, there are many exceptions today when it comes to technical subjects. When I was sent back to GCHQ as Director in 1995 I devoured books like that of Bruce Schneier on Applied Cryptography. ${ }^{4}$ No such published work could have existed in 1969 when I first joined GCHQ as the whole subject was then shrouded in secrecy. The pioneering work of Christopher Andrew at Cambridge has also filled the 'historical attention deficit disorder' to which he first drew attention. It is really important I believe that today's practitioners understand the history of their own chosen profession.

DVP: Why is this important in your opinion?

DO: As Isaac Newton famously wrote "If I have seen further than others, it is by standing on the shoulders of giants". We too readily overlook the struggles of previous generations that created what we take for granted today. And we are too quick to think of our problems as unique in the demands they place on us. Reflecting on what our predecessors achieved, often with only limited means and primitive technology, should help keep a sense of proportion and spur us on to greater achievements.

DVP: What was your initial assessment of the field of intelligence studies when you transitioned into academia?

DO: I was startled when I learnt just how popular the field had become in British universities. The War Studies Department at King's College on average has 70 students per year taking the MA intelligence degree and around 80 taking the second year BA course and we have $10 \mathrm{PhD}$ students working on the subject. It is the case, however, that so much of what is covered is English language scholarship on the US and on the UK intelligence experiences. Much less is available on continental European intelligence, although I am

\footnotetext{
${ }^{4}$ Bruce Schneier, Applied Cryptography: Protocols, Algorithms, and Source Code in C (New York: Wiley, 1993).
} 
glad to see French intelligence studies is catching up. There is a big gap when you then try to look globally. The massive Cambridge History of Intelligence and Security project for which I am editing a volume with Professor Peter Jackson aims to help fill that space. Another feature of the literature that struck me was the value of the work that comes from the US practice of encouraging movement between those serving in the administration and then moving to academia and think tanks. The UK is catching up to some extent, and I am glad to see a number of former colleagues becoming senior research fellows and visiting professors, not just from the intelligence agencies but from the wider national security and defence world.

DVP: What motivated you to write Securing the State?

DO: When I retired from government service, I realised I had been storing up, I might even say bottling up, observations from my experience in defence, in home affairs, and in the world of security and intelligence. I had been very privileged to have had the rare opportunity to carry senior responsibilities in each of those fields and to understand how important it is in a liberal democracy to maintain our freedoms in ways that respect our rights. So I felt I had something worth saying about what 'securing the state' really involves, not least the access to and understanding of secret intelligence. The trigger for the theme I chose for the book was a visit to Sienna and the wonderful late fourteenth century Lorenzetti frescoes of what makes for good government and for bad government with the fresco equivalent of a PowerPoint slide beautifully illustrating the relationship between intelligence, wisdom, social harmony and security. I wanted to portray a twenty-first century version of that vision.

DVP: Most former American intelligence officers prefer to write memoirs. Securing the State, and more recently Principled Spying, adopt a more academic approach. Why have you preferred this approach?

DO: British intelligence officers are strongly discouraged from writing personal memoirs! The academic approach suited me well as a vehicle for putting forward directly the conclusions of my thinking about security and intelligence without the temptation of betraying confidences. Both of my books were also written with the needs of scholars of the subject in mind, and provide the usual apparatus of references and notes for them to follow up.

DVP: As a practitioner-turned academic, do you think the literature on intelligence in history and the social sciences has much to offer to practitioners? And if so, what?

DO: I think there is a difference here between different fields of scholarship. History always has much to offer practitioners, not least to provide a sense of perspective from the experience of previous generations. And vice versa, historians too need to learn from intelligence history about some of the kinds of intelligence activity beneath the surface that may have shaped the historical record they are studying. But there are many other areas of scholarship that professionals must access. Modern neuroscience is, for example, an area of research with much to teach intelligence analysts about the cognitive biases to which they are subject. Now we are in the digital age, and practitioners must study the latest advances in computing, communications and artificial intelligence. And they must learn from lawyers, ethicists and social scientists about the changes in public attitudes to privacy and surveillance law. 
DVP: What should be the purpose of intelligence studies? Do you think scholars should conduct research on intelligence and keep a certain distance with government needs, or should researchers seek to meet government needs in the field of intelligence and security?

DO: The fundamental purpose of intelligence itself is to improve decision making by reducing the ignorance of those who have to make decisions. Secret intelligence fulfils that purpose in respect of information that others - dictators, terrorists, criminals and the like - do not want us to have. That makes it a unique sphere of human activity worthy of study. Secret intelligence provides invaluable social benefit but carries significant ethical risks and has to be surrounded with inevitable secrecy about the sources and methods being employed. As a human activity it is a legitimate subject for scholarship, just as is war and the study of its causes and consequences. Government and its agencies can benefit from such scholarship. At times government will also have specific research questions on which it is seeking help from academe, which I think is proper and welcome. But the intrinsic validity of intelligence studies remains regardless.

DVP: What issues should intelligence research focus on? What are the gaps in the literature?

DO: I invite students to think about their reading (and their choices of dissertation or research topic) in terms of a four-strand model derived from that of Stafford Thomas. ${ }^{5}$ There is first of all the historical and documentary tradition where there is always more to glean from research into the released archives. A recent example is Rory Cormac's work on the latest batch of files of the Information Research Department of the UK Foreign Office. ${ }^{6}$ Then there is the functional approach as a second strand, looking in detail at the methods of intelligence. There is almost too much on signals intelligence and Bletchley Park (2019 is the $100^{\text {th }}$ anniversary of GCHQ). The notable HUMINT cases are well researched such as those of Sorge, Penkovsky and Gordievsky, not to mention the Cambridge 5. But there are more gaps in the history of the other 'INTs'. The third strand is organisational and relational with questions that need research such as why some nations find it easier to form intelligence communities than others, and why some struggle with relationships between national intelligence and law enforcement. But, of course, it is the final strand of research that really matters, and that is the most difficult: what difference did good intelligence (or its absence) actually make? How far were policies influenced by intelligence assessments? Here there are major areas still to be researched.

DVP: Are those issues you are working on at the moment?

DO: Yes. My next book - How Spies Think: 10 Lessons from Secret Intelligence - will illustrate how the processes of rational analysis and hypothesis testing that intelligence analysts have developed can deliver important insights of policy significance and are of wider applicability in the commercial sphere. In our modern digital world of rumour, fake news, on-line deception and subversive propaganda it becomes ever more important to hold fast to the principles of sound Bayesian reasoning which I set out in the book.

\footnotetext{
${ }^{5}$ Stafford T. Thomas, 'Assessing Current Intelligence Studies', International Journal of Intelligence and Counterintelligence 2/2 (1988): 217-244.

${ }^{6}$ Rory Cormac, 'Techniques of covert propaganda: the British approach in the mid-1960s', Intelligence and National Security 34/7 (2019): 1064-1069.
} 
DVP: What issues should intelligence teaching focus on?

DO: The starting point has to be to get the students to understand fully the nature of their subject, what intelligence officers did in the past and do today and may do tomorrow and how they think. Then on that foundation intelligence studies teaching can look at past successes and failures, at conspiracies and deceptions, at the ethical and legal issues surrounding intelligence and security work, at the social implications of intelligence in liberal democracies and in the hands of autocratic states, and at the impact of technology, past and future. And that partial list illustrates that there are many disciplines that need to have an understanding of how the world of intelligence has interacted with them.

DVP: Let's turn our attention to recent developments. You have been an acute observer of technological changes and the way they are challenging intelligence practices in Western democracies and beyond. Do you think that the spread of digital computers and users has prompted a "revolution" in intelligence affairs?

DO: Yes, there is a digital revolution going on as we speak, not least as we see the use of artificial intelligence, Bayesian causal inference and advanced algorithms applied to big data sets to glean intelligence leads. But this is only the latest such revolution. In the late nineteenth century the electric telegraph and Samuel Morse's code led to a new form of strategic military intelligence from cable interception, as was seen in the American Civil War. In the early twentieth century it was Marconi's invention of radio that was quickly exploited for tactical battlefield and naval warfare purposes, establishing traffic analysis of communications data as a new source of intelligence. Then it was the computational innovations of Turing and others at Bletchley Park. Then quantum electrodynamics - the interaction of light and matter - with lasers allowing data to be stored and read at speed and microchips to make satellites and mobile computing devices possible. Then packet switched networks, the Internet and the Web, digital personal data and surveillance capitalism. Each scientific and technological revolution in our lives has had its intelligence spin-off. I invite my students to look at what is going on in pure science today that may generate technology over the next decade and imagine how it might impact the intelligence community. Quantum encryption and quantum computing, neuroscience, materials science, advanced AI [Artificial Intelligence] are just some of the examples they give me.

DVP: Given the place that the digital world plays in our daily lives, and the exponential number of opportunities for online surveillance both by state and non-state actors, how can liberal democracies avoid becoming "Big Brother"?

DO: I don't think we can get out of the dilemma by banning use of the relevant digital technologies. Bulk access to digital data for example does not have to imply "mass surveillance". We have to learn therefore to regulate the use of these technologies sensibly. By sensibly I mean in ways that allow the advantages for society to be made available. For example, insisting on adequate protection for personal data held by companies and government agencies yet allowing its regulated use for beneficial purposes such as public security and the use of personal health data for medical research. For intelligence and security purposes the UK has made a good start with the 2016 Investigatory Powers Act based on the three 'R's: primacy of the Rule of law; Regulation with independent judicial and Parliamentary oversight; and Restraint with intelligence officers having to justify their investigations as both necessary and proportionate. That provides a model for other nations who share our values, but there 
are many nations that do not and where the digital revolution will sadly lead to new forms of social control.

DVP: In this context, should citizens be more concerned about the data collection and analytical capabilities of the private sector (e.g. social media companies) or those of government intelligence agencies?

DO: In the UK, Parliament has recently put in place a legal framework and system of regulation for surveillance by the authorities, overseen by an independent and powerful judiciary, that should provide reassurance to the citizen. But no-one has yet worked out how far it would be desirable to regulate "surveillance capitalism" and what forms such regulation might take. We already have the example of Russian subversive interference in democratic elections and the exploitation and manipulation of social media to sow dissent inside our societies and encourage divisive and angry polarisation of political life. There is nothing special about these digital dirty tricks. Others will follow. I fear that for all its huge economic and social advantages the digital revolution is also bringing a coarsening of our democracy and our commitment to rationality.

DVP: Finally, what are your views on the potential impact of Brexit on intelligence cooperation between the United Kingdom and its European neighbours?

DO: Very briefly, the impact on existing patterns of cooperation between traditional intelligence agencies should be minimal since national security is a matter expressly stated in the Treaty of European Union (Article 4(2)) to be sole preserve of the member nations and therefore not an EU competence. Where we must expect problems is in the exchange of intelligence and data for law enforcement purposes, which is governed by EU arrangements such as through Europol and the Schengen agreements. It must be a priority post-Brexit to secure an EU/UK security treaty to allow the UK to continue to benefit from and contribute to these vital arrangements, in everyone's interest.

DVP: Thank you very much for your time.

\section{David Omand: a select bibliography}

'Can we have the pleasure of the grin without seeing the cat? Must the effectiveness of secret agencies inevitably fade on exposure to the light?', Intelligence and National Security 23/5 (2008): 593-607.

'Countering international terrorism: The use of strategy', Survival 47/4 (2005): 107-116.

'Creating intelligence communities', Public Policy and Administration 25/1 (2010): 5-9.

'Developing national resilience', The RUSI Journal 150/4 (2005): 14-18.

'Emergency planning, security and business continuity', The RUSI Journal 149/4 (2004): 2633.

'Ethical guidelines in using secret intelligence for public security', Cambridge Review of International Affairs 19/4 (2006): 613-628.

'Ethics and intelligence: A debate', International Journal of Intelligence and Counterintelligence 26/1 (2013): 38-63 [with Mark Phythian].

'From Nudge to Novichok', Working Paper, Helsinki: European Centre of Excellence for Hybrid Threats, May 2018.

'Into the future: a comment on Agrell and Warner', Intelligence and National Security 27/1 (2012): 154-156. 
'Introducing social media intelligence (SOCMINT)', Intelligence and National Security 27/6 (2012): 801-823.

'Is it time to Move Beyond the Intelligence Cycle: A UK Practicioner's Perspective', in Mark Pythian (ed.), Understanding the Intelligence Cycle, London, Routledge, 2014, 134148.

'Keeping Europe safe: counterterrorism for the continent', Foreign Affairs 95 (2016): 83-93.

'Nuclear deterrence in a changing world: the view from a UK perspective', The RUSI Journal 141/3 (1996): 15-22.

'Securing the State: National Security and Secret Intelligence', in Anders Rubing (ed.) The City between Freedom and Security, Berlin, Birkhauser Verlag, 2016, 129-152.

'Teaching Intelligence Analysts in the UK', Studies in Intelligence 52/4 (2008): 1-12 [with Michael Goodman].

'The Cycle of Intelligence', in Robert Dover, Michael Goodman and Claudia Hillebrand (eds.), Routledge Companion to Intelligence Studies, London: Routledge, 2013, 59-70.

'The dark net: policing the Internet's underworld', The Duke Policy Journal 32/4 (2015): 75 82.

'The future of intelligence: What are the threats, the challenges and the opportunities?', in Isabelle Duvesteyn, Ben de Jong, and Joop van Reijn, The Future of Intelligence. Challenges in the $21^{\text {st }}$ century, London, Routledge, 2014, 14-26.

'The terrorist threat to the UK in the post-9/11 decade', Journal of Terrorism Research 3/1 (2012): 6-12.

'The threats from Digital Subversion and Sedition', Journal of Cyber Policy 3/1 (2018): 523.

'Towards the discipline of social media intelligence' [with Carl Miller and Jamie Bartlett], in Chris Hobbs, Michael Moran, and Daniel Salisbury (eds.), Open Source Intelligence in the Twenty-First Century, London, Palgrave Macmillan, 2014, 24-43.

'Towards a new management strategy for defence', The RUSI Journal 134/3 (1989): 16-29.

'Understanding Bayesian Thinking, Prior and Posterior Probabilities and Analysis of Competing Hypotheses in Intelligence Analysis', in William Lahneman (ed.), The Art of Intelligence: Simulations, Exercises, and Games, New York: Rowman and Littlefield, 2014, 185-202.

'Understanding Digital Intelligence and the Norms that might Govern it', Global Commission on Internet Governance, Paper 8, London, Chatham House and Ottawa CIGI, March 2015.

'Understanding Digital Intelligence: A British View', National Security and Counterintelligence in the Era of Cyber Espionage, Hershey, Information Science Reference, 2016, 97-121.

'What should be the Limits of Counter-Terrorism Policy?', in Richard English (ed.), Illusions of Terrorism and Counter-Terrorism, Oxford, Oxford University Press, 2015.

How Spies Think: 10 Lessons from Secret Intelligence, London, Penguin Viking, forthcoming June 2020.

Principled spying. The ethics of secret intelligence, with Mark Phythian (Oxford and Washington D.C., Oxford/ Georgetown University Press, 2018.

Securing the State, London and New York, Hurst/Columbia University Press, 2010. 